This item was submitted to Loughborough's Research Repository by the author.

Items in Figshare are protected by copyright, with all rights reserved, unless otherwise indicated.

\title{
A new simplified protocol for copper(I) alkyne-azide cycloaddition reactions using low substoichiometric amounts of copper(II) precatalysts in methanol
}

PLEASE CITE THE PUBLISHED VERSION

http://dx.doi.org/10.1055/s-0035-1560526

PUBLISHER

(c) Georg Thieme

VERSION

AM (Accepted Manuscript)

PUBLISHER STATEMENT

This paper was accepted for publication in the journal SYNLETT and the definitive published version is available at https://doi.org/10.1055/s-0035-1560526

LICENCE

CC BY-NC-ND 4.0

\section{REPOSITORY RECORD}

Buckley, Benjamin, Maria M.P. Figueres, Amna N. Khan, and Harry Heaney. 2019. "A New Simplified Protocol for Copper(i) Alkyne-azide Cycloaddition Reactions Using Low Substoichiometric Amounts of Copper(ii) Precatalysts in Methanol". figshare. https://hdl.handle.net/2134/21368. 


\title{
A New Simplified Protocol for Copper(I) Alkyne-Azide Cycloaddition Reactions Using Low Sub-Stoichiometric Amounts of Copper(II) Pre- Catalysts in Methanol
}

\author{
Benjamin R. Buckley, Maria M. P. Figueres, Amna N. Khan, and Harry Heaney* \\ Department of Chemistry, Loughborough University, Loughborough, Leicestershire, LE11 3TU, UK \\ E-mail: b.r.buckley@lboro.ac.uk,m.m.pardo-figueres@lboro.ac.uk,amnankhan@gmail.com, h.heaney@lboro.ac.uk \\ Received: The date will be inserted once the manuscript is accepted. \\ Dedicated to Professor Steven V. Ley FRS for his excellent achievements in organic chemistry on the occasion of his 70th birthday.
}

\begin{abstract}
Copper(II) carboxylates are reduced efficiently by methanol in the presence of alkynes and form yellow alkynylcopper(I) polymeric pre-catalysts that are involved with azides, in the absence of added ligands, in the catalytic cycles that result in the formation of 1,4-disubstituted-1,2,3-triazoles.
\end{abstract}

Key words Alkyne, azide, copper(I), cycloaddition, triazole.

The disclosure of highly regioselective copper(I) catalysed intermolecular alkyne-azide cycloaddition (CuAAC) reactions by Meldal and Sharpless and their co-workers, ${ }^{1}$ has been followed each year by a very large number of reports of the preparation of triazoles that have been used for a variety of purposes. Click CuAAC reactions have become perhaps the most widely studied of all copper-catalysed reactions. ${ }^{2}$ The use of sodium ascorbate together with copper(II) sulfate, in aqueous $t$-butanol ${ }^{1 \mathrm{c}}$ is probably the most currently used $\mathrm{CuAAC}$ protocol.

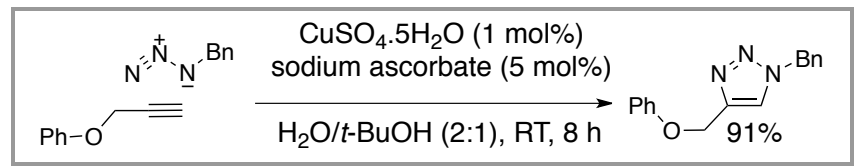

Scheme 1 The copper(II) sulfate/sodium ascorbate protocol for a $\mathrm{CuAAC}$ reaction.

However, in addition to examples involving the direct use of copper(I) salts, ${ }^{1 \mathrm{a}, \mathrm{b}, 3}$ there are other ways of generating the copper(I) state. For example, reactions of metallic copper together with copper(II) salts provides a method where the presence of ascorbate or its oxidation product may have a deleterious effect. ${ }^{4}$ Other catalyst systems include a copper nanocluster, ${ }_{7}^{5}$ copper(I) zeolites, ${ }^{6}$ a copper-maganese spinel oxide, ${ }^{7}$ copper(I) oxide "on water", 8 and copper on carbon. 9a,b Our previous studies of $\mathrm{CuAAC}$ reactions centred on copper(II) pre-catalysts in the absence of ligands, using copper(II) hydroxyacetate, ${ }^{10}$ and more recently Gerhardite (copper(II) hydroxynitrate), the copper(II) species present in "Copper-in-Charcoal".

The use of copper(II) acetate in CuAAC reactions has been studied in considerable detail by Zhu and his coworkers, paying particular attention to reactions involving chelating azides as well as other ligands. ${ }^{12}$ The reduction of a copper(II) 1,10-phenantholine complex to the related copper(I) complex in propan-2ol implicated the alcohol as the reducing agent. ${ }^{13}$ In an earlier study we established that the phenylethynylcopper(I) polymer was involved in CuAAC reactions by the interaction of phenylacetylene with copper(II) hydroxyacetate in easily oxidisable alcohols, including isopropanol. ${ }^{10 \mathrm{~b}}$ The present investigation was undertaken for a number of reasons. First, the original protocol, shown in Scheme 1, involved the addition of a solution of copper(II) sulfate to a solution of an alkyne and an azide in a mixture of $t$ butanol, water, and a five-fold excess of sodium ascorbate. Second, no additional ligands were used. Third, the acidities of ascorbic acid (pKa ca. 4.1) and acetic acid (pka 4.76) are almost identical, and fourth, $\pi$-complexation of alkynes by metallic ions such as copper(I) reduce the acidity of alkynes by $c a$. $10 \mathrm{pKa}$ units. ${ }^{14}$ The recent report of the use of a copper(II)tren pre-catalyst ${ }^{15}$ in $\mathrm{CuAAC}$ reactions, and the use of copper(I) oxide in the presence of dioxygen, ${ }^{16}$ prompts this report of a highly efficient and simple protocol that uses copper(II) carboxylates in methanol.

We observed, at an early stage of the present investigation, that a solution of phenylacetylene and copper(II) acetate in wet degassed methanol at ambient temperature gave the yellow polymeric phenylethynylcopper(I), ${ }^{17}$ in an almost quantitative yield after $c a$. 2 days; similarly, copper(II) formate gave the same product more rapidly. The absence of the Glaser reaction product, 1,4-diphenylbuta-1,3diyne, as shown by GC/MS, confirmed that methanol was the reducing agent. ${ }^{18}$ Reactions using copper(II) salts in solvents such as acetonitrile result in the formation of Glaser products in order to reduce $\mathrm{Cu}$ (II) salts to the $\mathrm{Cu}(\mathrm{I})$ pre-catalyst required to catalyse $\mathrm{CuAAC}$ reactions. ${ }^{10 \mathrm{a}}$

Our earlier studies of CuAAC reactions ${ }^{10}$ showed that arylethynylcopper(I) polymers are efficient precatalysts that are formed in high yields and that reactions carried out at ambient temperature, in the absence of added ligands, were complete after $c a 15$ h. ${ }^{10 \mathrm{~b}} \mathrm{CuAAC}$ reactions were shown to proceed more rapidly in microwave assisted reactions. Importantly, that alkynylcopper(I) polymers are involved in the catalytic cycle in the absence of ligands, was established by crossover reactions. ${ }^{10 a, b, 2 f}$ For example, in a reaction of $p$-tolylethyne with benzylazide using a 
catalytic amount of phenylethynylcopper(I), we recovered $p$-tolylethynyl-copper(I).

We therefore carried out reactions of phenylacetylene with benzylazide at ambient temperature using 1 mol\% of copper(II) acetate in methanol, in order to establish that methanol could be used as the reducing agent and obtained 1-benzyl-4-phenyl-1,2,3-triazole in $71 \%$ yield after $3 \mathrm{~d}$ : a similar reaction, carried out at 50 ${ }^{\circ} \mathrm{C}$ for $4 \mathrm{~h}$ gave the same product in $78 \%$ yield. Reactions of benzylazide with octa-1,7-diyne or nona1,8-diyne were also carried out at $50{ }^{\circ} \mathrm{C}$ for $4 \mathrm{~h}$ and gave the expected products in $72 \%$ and $69 \%$ yields respectively. ${ }^{19,21}$ The reaction of 3-trifluoromethylbenzyl azide with phenylacetylene or $p$-tolyl-acetylene and copper(II) acetate (1 mol\%), at ambient temperature in degassed methanol, proceeded very slowly and gave, after $12 \mathrm{~h}$, the expected triazole derivatives in only $37 \%$ and $51 \%$ respectively. We then carried out a series of microwave assisted reactions, using a mixture of $p$-tolylacetylene and 3trifluoromethyl-benzyl azide together with amounts of copper(II) acetate, starting with $5 \mathrm{~mol} \%$, in order to establish the minimum reasonable amount of the precatalyst required. Reactions using $0.1 \mathrm{~mol} \%$ of copper(II) acetate gave the expected triazole derivative, shown in Scheme 2, in an almost quantitative yield. ${ }^{23}$ As our earlier results had shown that CuAAC reactions can be carried out at ambient temperatures using pre-formed alkynylcopper(I) polymers, ${ }^{10 \mathrm{~b}}$ in the absence of added ligands, the present results suggest that the reduction of copper(II) to give the pre-catalytic $\mathrm{Cu}(\mathrm{I})$ species, is the slow step in our new protocol.

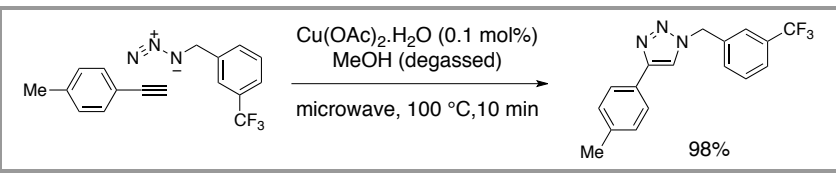

Scheme 2 The copper(II) acetate/methanol protocol for CuAAC reactions

Reactions using other copper(II) carboxylates as precatalysts for CuAAC reactions, were carried out; but none was found to be superior to copper(II) acetate.

Table 1 Influence of copper(II) salts on the CuAAC reaction. ${ }^{a}$

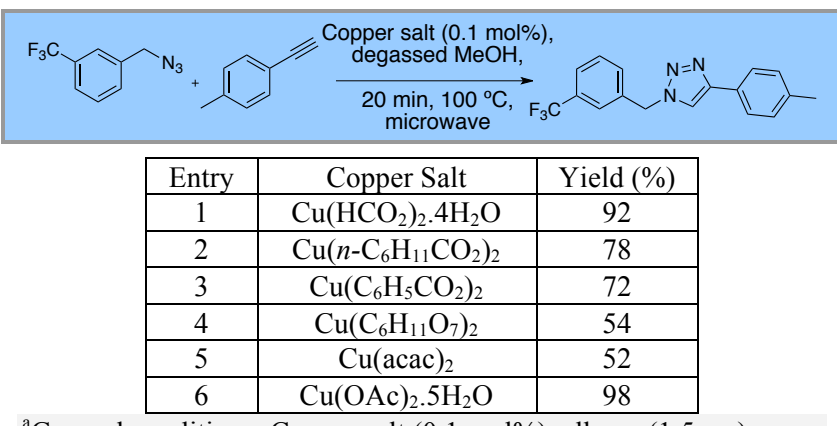

${ }^{\mathrm{a}}$ General conditions: Copper salt $(0.1 \mathrm{~mol} \%)$, alkyne (1.5 eq.), azide (1.0 eq.), degassed $\mathrm{MeOH}, 100^{\circ} \mathrm{C}$, microwave, $20 \mathrm{~min}$;

${ }^{\mathrm{b}}$ Isolated yield after chromatography.
Copper(II) acetylacetonate in methanol did function as a pre-catalyst; however, as anticipated, it was poor by comparison to the copper(II) carboxylates that we studied. The results of the trial reactions are shown in Table 1.

The optimum conditions (Table 1, Entry 6) were then applied to a range of alkyne/azide combinations to afford the corresponding triazoles. In some cases a higher loading of copper acetate was required to obtain the best yields in the cycloaddition reactions (Table 2). Although many of the reactions reported were carried out using degassed methanol; reactions can be carried out in the presence of air since the reducing agent methanol, like ascorbate in the Sharpless protocol, ${ }^{1 \mathrm{c}}$ is present in a very large excess.

\section{Table 2 Application to a range of substrates.}

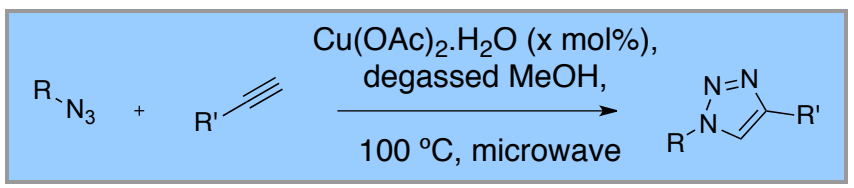

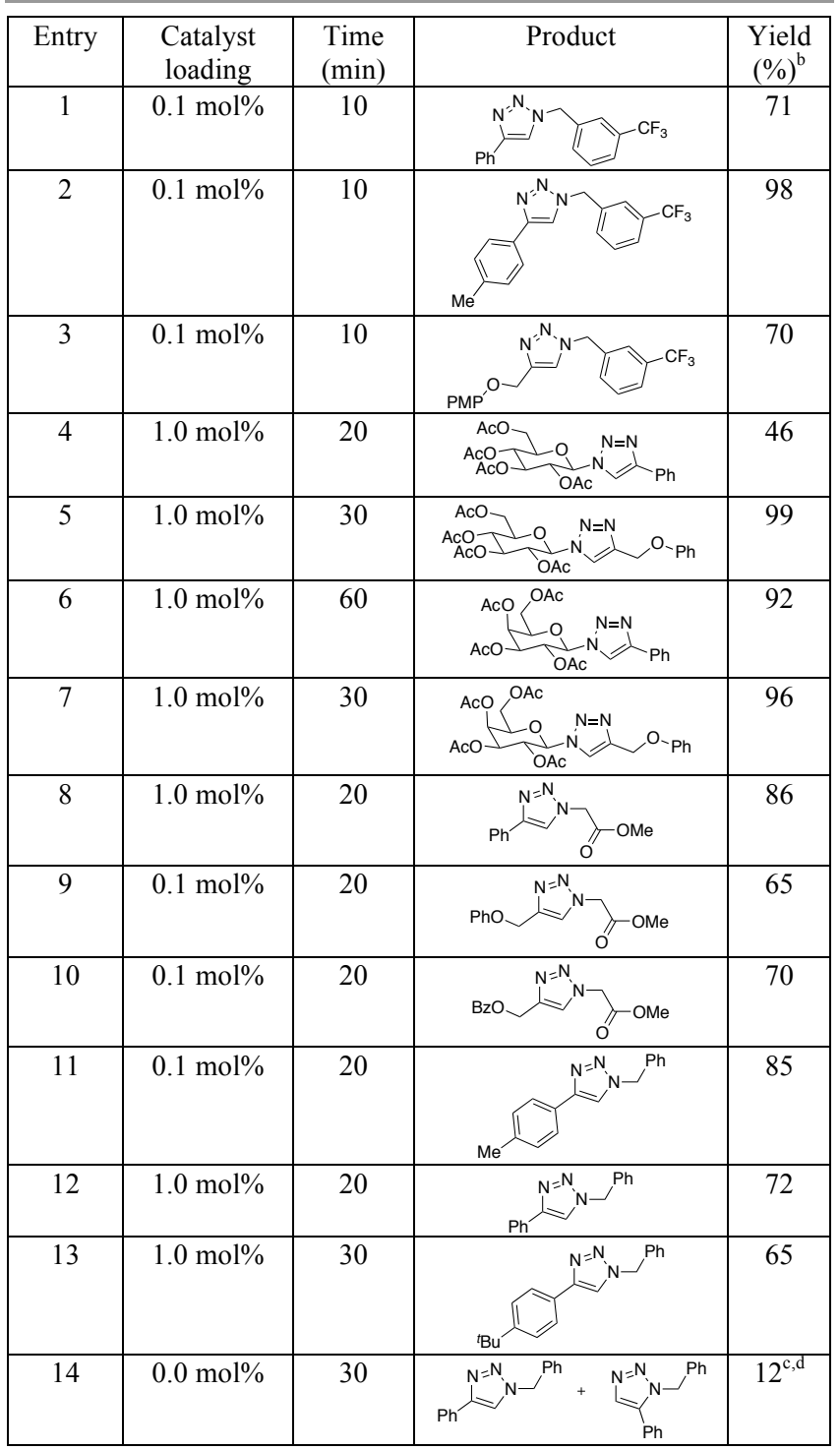


${ }^{\mathrm{a}}$ General conditions: Copper salt $(0.1 \mathrm{~mol} \%)$, alkyne (1.5 eq.), azide (1.0 eq.), degassed $\mathrm{MeOH}, 100{ }^{\circ} \mathrm{C}$, microwave, $20 \mathrm{~min}$; ${ }^{\mathrm{b}}$ Isolated yield after chromatography; ${ }^{\mathrm{c}}$ Conversion evaluated by ${ }^{1} \mathrm{H}$ NMR spectroscopy by integration of benzylazide $\mathrm{CH}_{2}$ vs benzyl $\mathrm{CH}_{2}$ in the triazole products; ${ }^{\mathrm{d}}$ sum of both regioisomers

In summary, we have shown that a simple protocol can be used to obtain good to excellent yields of 1,4disubstituted-1,2,3-triazoles, that involve alkynylcopper(I) polymeric pre-catalysts in the CuAAC reactions carried out in the absence of added ligands. Also, that whereas phenylethynylcopper(I) has been prepared by a number of methods, ${ }^{17}$ our present results demonstrate that reactions of alkynes in methanol in the presence of, for example copper(II) acetate, provides the simplest method of preparing the alkynylcopper(I) polymers. The new protocol may also stimulate the use of alkynylcopper(I) compounds as pre-catalysts in a variety of other reactions. In addition to other recent examples, ${ }^{24}$ alkynylcopper(I) polymers may be involved for example in the flow generation of azides used in the copper(I) catalyzed preparation of allenes from terminal alkynes. ${ }^{25}$

Supporting Information for this article is available online at http://www.thiemeconnect.com/products/ejournals/journal/10.1055/s00000083 .

\section{Acknowledgment}

The authors are grateful to The Higher Education Commission of Pakistan for a visiting fellowship (to A.N.K.) and the EU Lifelong Learning Programme for support (to M.M.P.F), and Loughborough University for research funding. B.R.B. also thanks Research Councils UK for a RCUK fellowship.

\section{References}

(1) a) Tornøe, C. W.; Meldal, M. Peptidotriazoles: copper(I)-catalysed 1,3-dipolar cycloadditions on solid phase; Peptides, Proc. Am. Pept. Symp., American Peptide Society and Kluwer Academic Publishers, San Diego, 2001, 263. b) Meldal, M.; Tornøe, C. W. J. Org. Chem., 2002, 67, 3057. c) Rostovsev, V. V.; Fokin, V. V.; Green, L. G.; Sharpless, K. B. Angew Chem. 2002, 114, 2708.

(2) For reviews see for example, a) Bock, V. D.; Hiemstra, H.; van Maarseveen, J. H. Eur. J. Org. Chem., 2006, 51. b) Meldal, M.; Tornøe, C. W. Chem. Rev., 2008, 108, 2952. c) Amblard, F.; Cho, J. H.; Schinazi, R. F. Chem. Rev., 2009, 109, 4207. d) Chem Soc. Rev., 2010, 39, 1221-1408. e) Topics in Heterocycl. Chem., 2012, 28, 1232. f) Berg, R.; Straub, B. F. Beilstein J. Org. Chem., 2013, 9, 2715. g) Haldón, E.; Nicasio, M. C.; Pérez P. J. Org. Biomol. Chem. 2015, 13, 9528.

(3) see for example, a) Malkoch, M.; Schleicher, K.; Drckenmuller, E.; Hawker, C. J.; Russell, T. P.; Wu, P.; Fokin, V. V. Macromolecules, 2005, 35, 3663. b) Ackermann, L.; Potukuchi, H. K.; Landsberg, D.; Vicente, R. Org. Lett., 2008, 10, 3081. c) Qin, A.; Lam J. W. Y.; Tang, L.; Jim, C. J. W.; Zhao, H.; Sun, J.; Tang, B. Z. Macromolecules, 2009, 42, 1421.
(4) a) Appukkuttan, P.; Dehaen, W.; Fokin, V. V.; Van der Eycken, E. Org. Lett., 2004, 6, 4223. b) Himo, F.; Lovell, T.; Hilgraf, R.; Rostovtsev, V. V.; Noodleman, L.; Sharpless, K. B.; Fokin, V. V. J. Am. Chem. Soc. 2005, 127, 210. c) Urankar, D.; Košmrlj, J. J. Comb. Chem., 2008, 10, 981. d) Chandrasekhar, S.; Seenaiah, M.; Kumar, A.; Reddy, C. R.; Mamidyala, S. K.; Kumar, C. G.; Balasubramanian, S. Tetrahedron Lett., 2011, 52, 806.

(5) Pachón, L. D.; Maarseveen, J. H.; Rotherberg, G. Adv. Synth. Catal., 2005, 347, 811. see also Moore, E.; McInnes, S. J.; Vogt, A.; Voelker, N. H. Tetrahedron Lett., 2011, 52, 2327.

(6) a) Chassaing, S.; Kumarraja, M.; Sido, A. S. S.; Pale, P.; Sommer, J. Org. Lett., 2007, 9, 883. b) Chassaing, S.; Sido, A. S. S.; Alix, A.; Kumarraja, M.; Pale, P. Chem. Eur. J. 2008, 14, 6713.

(7) Yousuf, S. K.; Mukherjee, D.; Singh, B.; Maity, S.; Taneja, S. C. Green Chem., 2010, 12, 1568.

(8) Wang, K.; Bi, X.; Liao, P.; Fang, Z.; Meng, X.; Zhang, Q.; Liu, Q.; Ji, Y. Green Chem., 2011,13, 562.

(9) a) Lipshutz, B. H.; Taft, B. R Angew Chem. 2006, 118 , 8415. b) Lee, C.-T.; Huang, S.; Lipshutz, B. H. $A d v$. Synth. Catal., 2009, 351, 3139.

(10) a) Buckley, B. R.; Dann, S. E.; Harris, D. P.; Heaney, H.; Stubbs, E. C. J. Chem. Soc., Chem. Commun. 2010, 46, 2274. b) Buckley, B. R.; Dann, S. E.; Heaney, H. Chem. Eur. J. 2010, 16, 6278. c) Buckley, B. R.; Dann, S. E.; Harris, D. P.; Heaney, H.; Stubbs, E. C. Eur. J. Org. Chem., 2011, 770.

(11) Buckley, B. R.; Butterworth, R.; Dann, S. E.; Heaney, H.; Stubbs, E. C. ACS Catal., 2015, 5, 793.

(12) a) Brotherton, W. S.; Michaels, H. A.; Simmons, J. T.; Clark, R. J.; Dalal, N. S.; Zhu, L. Org. Lett., 2009, 11, 4954. b) Kuang, G.-C.; Michaels, H. A.; Simmons, J. T.; Clark, R. J.; Zhu, L. J. Org. Chem., 2010, 75, 6540. c) Brotherton, W. S.; Guha, P. M.; Phan, H.; Clark, R. J.; Shatruk, M.; Zhu, L. Dalton Trans., 2011, 40, 3655. d) Kuang, G.-C.; Guha, P. M.; Brotherton, W. S.; Simmons, J. T.; Stankee, L. A.; Nguyen, B. T.; Clark, R. J.; Zhu, L. J. Am. Chem. Soc., 2011, 133, 13984. e) Michaels, H. A.; Zhu, L. Chem. Asian J., 2011, 5, 2825. f) Guha, P. M.; Phan, H.; Kinyon, J. S.; Brotherton, W. S.; Sreenath, K.; Simmons, J. T.; Wang, Z,; Clark, R. J.; Dalal, N. S.; Shatruk, M.; Zhu, L. Inorg. Chem., 2012, 51, 3465. g) Yuan, Z.; Kuang, G.-C.; Clark, R. J.; Zhu, L. Org. Lett., 2012, 14, 2590.

(13) Kirai, N.; Yamamoto, Y. Eur. J. Org. Chem., 2009, 1864.

(14) Himo, F.; Lovell, T.; Hilgraf, R.; Rostovtsev, V. V.; Noodleman, L.; Sharpless, K. B.; Fokin, V. V. J. Am. Chem. Soc., 2005, 127, 210.

(15) Harmand, L.; Lescure, M.-H.; Candelon, N.; Duttine, M.; Lastécouères, D.; Vincent, J. M. Tetrahedron Lett., 2012, 53, 1417.

(16) Alonso, F.; Moglie, Y.; Radivoy, G.; Yus, M. Synlett, 2012, 2179.

(17) For some earlier methods of preparation see, for example: a) Sazonova, V. A.; Kronrod, N. Ya. Zh. Obshch. Khim. 1956, 26, 1876; Chem. Abs. 1957, 51, 4981c. b) Castro, C. E.; Stephens, R. D. J. Org. Chem. 1963, 28, 2163. c) Stephens, R. D.; Castro, C. E. J. Org. Chem. 1963, 28, 3313. d) Owsley, D.C.; Castro, C. E. Org. Synth. Coll. 1988, 6, 916. e) Atkinson, R. E.; Curtis, R. F.; Taylor, J. A. J. Chem. Soc. C 1967, 578. f) Ito, H.; Arimoto, K.; Sensui, H.-o.; Hosomi, A. Tetrahedron Lett. 1997, 38, 3977.

(18) Glaser reaction products have been observed previously when using $\mathrm{Cu}$ (II) salts in the absence of a reducing agent. See a) Kamata, K.; Kotani. M.; Yamaguchi, K.; 
Mizono, N. Angew Chem. Int. Edn. 2008, 47, 2407. b) Kamata, K.; Nakagawa, Y.; Tamaguchi. K.; Mizono, N. J. Am. Chem. Soc., 2008, 130, 15304. c) reference 10c.

(19) Bis-triazole prepared from 1,7-octadiyne and benzyl azide. ${ }^{20}$ Benzyl azide $(0.15 \mathrm{~g}, 1.1 \mathrm{mmol})$ and 1,7 octadiyne $(0.053 \mathrm{~g}, 0.5 \mathrm{mmol})$ were added to a $3 \mathrm{~mL}$ vial containing methanol $(2 \mathrm{~mL})$ which was fitted with a magnetic stirrer bar. Copper(II) acetate mono-hydrate was added $(1 \mathrm{mg}, 0.005 \mathrm{mmol}, 0.1 \mathrm{~mL}$ from a stock solution in methanol containing $10 \mathrm{mg} / \mathrm{mL}$ ) and the vial was closed. The reaction mixture was then stirred and heated at $50^{\circ} \mathrm{C}$ for $4 \mathrm{~h}$ on a stirrer hotplate fitted with an aluminium vial holder and allowed to cool. The colourless precipitate was filtered, washed with cold methanol $(2 \times 5 \mathrm{~mL})$, diethyl ether $(5 \mathrm{~mL})$ and allowed to dry in air to give colourless crystals $(0.13 \mathrm{~g}, 72 \%)$; m.p. $156-158{ }^{\circ} \mathrm{C} ;{ }^{1} \mathrm{H}$ NMR $\left(400 \mathrm{MHz}, \mathrm{CDCl}_{3}\right) \delta=7.35-$ $7.34(6 \mathrm{H}, \mathrm{m}), 7.26-7.22(4 \mathrm{H}, \mathrm{m}), 7.17) 2 \mathrm{H}, \mathrm{s}), 5.47(4 \mathrm{H}$, s), 2.72-2.68 (4H, m), 1.72-1.69 (4H, m) ppm; ${ }^{13} \mathrm{C}$ NMR $\left(100 \mathrm{MHz}, \mathrm{CDCl}_{3}\right) \delta=148.7,135.2,129.3,128.8$, 128.2, 120.9, 54.2, 29.1, 25.7 ppm; HR-MS $\mathrm{C}_{22} \mathrm{H}_{24} \mathrm{~N}_{6} \mathrm{Na}$ $(\mathrm{m}+\mathrm{Na})$ calcd 395.1960 , obs. 3955.1959 .

(20) Saha, S.; Kaur, M.; Bera, J. K. Organomet. 2015, 34, 3047.

(21) Bis-triazole prepared from 1,8-nonadiyne and benzyl azide. ${ }^{22}$ A similar reaction gave colourless crystals $\left(0.13\right.$ g, 69\%) m.p. $121-123{ }^{\circ} \mathrm{C} ;{ }^{1} \mathrm{H}$ NMR $(400 \mathrm{MHz}$, $\left.\mathrm{CDCl}_{3}\right) \delta=7.37-7.35(6 \mathrm{H}, \mathrm{m}), 7.26-7.22(4 \mathrm{H}, \mathrm{m}), 7.17$ $(2 \mathrm{H}, \mathrm{s}), 5.48(4 \mathrm{H}, \mathrm{s}), 2.67(4 \mathrm{H}, \mathrm{t}, J=9.6 \mathrm{~Hz}), 1.71-1.60$ (4H, m), 1.40-1.37 (2H, m) ppm; ${ }^{13} \mathrm{C}$ NMR $(100 \mathrm{MHz}$, $\left.\mathrm{CDCl}_{3}\right) \delta=148.9,135.2,129.3,128.8,128.2,120.8$, 54.2, 29.3, 28.9, 25.8 ppm; HR-MS $\mathrm{C}_{23} \mathrm{H}_{26} \mathrm{~N}_{6} \mathrm{Na}$ $(\mathrm{m}+\mathrm{Na})$ calcd 409.2117, obs. 409.2113.

(22) Smith, C. D.; Baxendale, I. R.; Lanners, S.; Hayward, J. J.; Smith, S. C.; Ley, S. V. Org. Biomol. Chem. 2007, 5 , 1559.

(23) Table 2, Entry 2: Triazole prepared from $p$ tolylethyne and 3-trifluoromethylbenzyl azide. 3Trifluoromethylbenzyl azide $(0.34 \mathrm{~g}, 1.7 \mathrm{mmol})$ and $p$ tolylethyne $(0.30 \mathrm{~g}, 2.6 \mathrm{mmol})$ were added to a microwave tube $(5 \mathrm{~mL})$ fitted with a magnetic stirrer bar. Copper (II) acetate mono-hydrate (3.4 mg, 0.017 mmol) was added and the mixture suspended in methanol $(5 \mathrm{~mL})$. The reaction mixture was then heated in the microwave apparatus at $100{ }^{\circ} \mathrm{C}$ for $20 \mathrm{~min}$ and allowed to cool. The reaction mixture was added to EtOAc $(50 \mathrm{~mL})$ and water $(50 \mathrm{~mL})$, separated and the aqueous layer extracted with EtOAc $(2 \times 50 \mathrm{~mL})$. The EtOAc layers were evaporated under reduced pressure to give an off-white solid which after recystallisation from diethyl ether gave the product as colourless crystals $(0.53 \mathrm{~g}, 98 \%)$ m.p. $128-130{ }^{\circ} \mathrm{C} ;{ }^{1} \mathrm{H}$ NMR $(400$ $\left.\mathrm{MHz}, \mathrm{CDCl}_{3}\right) \delta=7.74-7.72(3 \mathrm{H}, \mathrm{m}), 7.66-7.61(2 \mathrm{H}, \mathrm{m})$, $7.55-7.48(2 \mathrm{H}, \mathrm{m}), 7.25(2 \mathrm{H}, \mathrm{d}, J=7.6 \mathrm{~Hz}), 5.65(2 \mathrm{H}$, s), $2.39(3 \mathrm{H}, \mathrm{s}) \mathrm{ppm} ;{ }^{13} \mathrm{C} \mathrm{NMR}\left(100 \mathrm{MHz}, \mathrm{CDCl}_{3}\right) \delta=$ $148.6,138.2,135.8,131.5(\mathrm{q}, J=32.2 \mathrm{~Hz}), 131.3$, $129.8,129.6,127.4,125.67$ (q), 125.62, 124.7 (q, $J=$ $3.7 \mathrm{~Hz}), 123.5$ (q, $J=271.2 \mathrm{~Hz}), 122.3,119.6,119.2$, 53.6. $21.4 \mathrm{ppm}$.

(24) a) Zuidema, E.; Bolm, C. Chem. Eur. J. 2010, 16, 4181. b) Albaladejo, M. J.; Alsonso, F.; Moglie, Y.; Yus, M. Eur. J. Org. Chem. 2012, 3093. c) Buckley, B. R.; Heaney, H; Khan, A. N. Chem. Eur. J. 2012, 18, 3855. d) E.-H. Zou, A. J. Johansson, E. Zuidema, Bolm, C., Chem. Eur. J. 2013, 19, 8144.

(25) Poh, J.-S.; Tran, D. N.; Battilocchio, C.; Hawkins, J. M.; Ley, S. V. Angew Chem. Int. Edn. 2015, 54, 7920. 


\section{CuAAC Reactions Using Cu(II)OAc 2 As Pre-Catalyst}

\section{Manuscript submission checklist}

- Statement of significance of work.

- Full mailing address, telephone, and fax numbers and e-mail address of the corresponding author.

- Graphical abstract.

- 5 key words.

- Original Word file.

- Original graphics files.

Proceed to submit your article via our online submission system at http://mc.manuscriptcentral.com/synlett. 